\title{
The Impact of the Internal Variables on Water Security in the Middle East (Water is a Foundation for Human Prosperity)
}

\author{
Dr. Mohammad Salim Al-Rawashdeh ${ }^{1}$, Dr Jebreel Ajreed Al-Odat ${ }^{2}$ \\ ${ }^{1}$ Associated Professor, International Relations, AL-BALQA'A APPLIED UNIVERSITY, Princess Alia College for Applied and social \\ sciences, Hashimit Kingdom f Jordan- Amman
}

${ }^{2}$ Associated professor, Sport Physical Education, AL-BALQA'A APPLIED UNIVERSITY.=, Princess Alia College for Applied and social sciences, Hashimit Kingdom of Jordan- Amman.

\begin{abstract}
This paper deals with the origins of international conflicts over the use of rivers, lakes, or ground water aquifers. The Middle East (ME) has long balanced the competing water demands of households, industry, and agriculture. Careful management of water resources has been an absolute necessity in this region where annual renewable water supplies average about 435.2 billion cubic meters (BCM), compared to Africa's 3,950 BCM, Asia's 12,009 BCM, and the world total of 43,764 BCM. The Middle East region's water security and internal variables has been worsening since 1960s, has not become a political issue because it has been possible to deemphasize the problem. As it is fundamental to the internal variable in Middle East such as, political changes and tensions, social, economic, and environmental sustainability of every community and every political economy, water is a strategic resource. In political economies where water sustainability is narrowly defined as water self-sufficiency, water will be identified as a particularly strategic resource. A regional security complex is defined as the integration of regional relations resulting from the rapport de forces particular to the region, which is determined by asymmetries of power, the Middle East region, with its many ideological, religious, and geographical disputes, extensive water resources, such as the Nile, Tigris and Euphrates river valleys, are coming under increasing population, irrigation, and energy pressure. And every major river in the region crosses international borders.
\end{abstract}

Keywords: internal variables, water security, regional security.

The impact of the internal variables on water security in the Middle East

\section{Introduction}

Logically, as the overall world population has increased, per capita water availability has decreased. The imbalance between populations and water supplies in many countries, however, is pushing those countries toward conditions of "water stress" and "water scarcity", which affects the water security.

In this paper I would like to address some of the growing internal and global challenges of dealing/with the devastating effects of increasing water scarcity and declining water quality. Across the planet, in developing and developed regions alike, poor governance and mismanagement of natural resources coupled with rising population growth, increasing urbanization, and economic development have led to a growing imbalance between water supply and demand.

The aim of this paper is to analyse the causes of international conflicts over freshwater resources and to attempt to identify the conditions under which such conflicts may be resolved.

The Middle East is the most water-stressed region in the world, registering the lowest internal water resources per capita rates, since the region accounts for only $1.1 \%$ of the global renewable water resources. Water is a renewable but limited resource, with no substitute.
Water has been and remains a central issue in the Levant security sub-complex. National and international political processes tend to link water with other issues, and thereby complicate riparian relations and multi-lateral and multiissue negotiations. Political processes can just as readily obscure and de-link awareness of tightly bound systems and of the inseparability of elements in complex economic processes.

This narrative of the development of collective action over water in the Middle East has shown how the participating economies and global interests have constructed knowledge on the region's water resources during the three hydropolitical regimes since the late nineteenth century. Resource constraints have been real since the middle of the Cold War era, but they have had limited impact on the way the increasingly scarce fresh water of the region has been managed. This lack of impact is due to the fact that the water predicament was constructed out of the political environment, which has determined, and continues to determine, water use and water policy.

This imbalance is reaching crisis proportions in many regions. It will have even more significant consequences for economic development, stability and security unless the there is a more dramatic and urgent international response.

The Middle East can be largely divided into two groups:

(1) Those that have low levels of renewable water resources, such as flowing rivers, and must rely on groundwater and desalination for most of their supply. 


\section{International Journal of Science and Research (IJSR) \\ ISSN (Online): 2319-7064}

Index Copernicus Value (2013): 6.14 | Impact Factor (2015): 6.391

(2) Those that get much of their water from river systems they share with other countries. The former group includes, among others, Bahrain, the Gaza Strip, Kuwait, Oman, Qatar, Saudi Arabia, the United Arab Emirates (UAE), and Yemen, while the latter group consists of Egypt, Iraq, Iran, Jordan, Lebanon, the West Bank, and Syria.

However, high quality water supplies provide a basis for the growth and development of human social, economic, cultural and political systems. Conversely, economic stagnation and political instability will persist or worsen in Middle East region, where the quality and reliability of water supplies remain uncertain.

Traditionally, water and security have been treated as separate entities; when they were combined it was often as 'water security' such as in relation to safely procedures or security concerns for water infrastructures and transportation. Security studies have a long tradition of interpretation in military, strategic, and political contexts, while water has been regarded from a geo-science perspective or strictly as a water management issue.

In the late-eighties however, the epistemic community began to analyse the nexus in a broader sense, and scholars like, Westing (1986), stated that comprehensive security has two intertwined components: political security, with its military, economic and humanitarian subcomponents, and environmental security, including the protection and use of resources and the environment. Much of the research on environment and security was in fact more about strategic resources like water and security aspects than about environmental issues in a broad sense.

\section{Water problems are destabilizing.}

\section{geopolitically}

The water scarcity and poor water quality as well as the internal political tensions have the potential to destabilize isolated regions within countries, whole countries, or entire regions sharing limited sources of water. There is an increasing likelihood of social strife and even armed conflict resulting from the pressures of water scarcity and mismanagement. Like Egypt, Iraq, Syria, Iran, Lebanon, and Yemen.

The water scarcity and poor water quality could lead to increased potential for domestic instability and heightened transnational tensions. History shows that in Middle East, water has been a source of considerable cooperation between nations sharing water resources. However, increasing populations and water scarcities may bring about a different future. In the years ahead, instability or conflict related to water supplies will likely take two forms:

(1) Domestic unrest caused by the inability of governments to meet the food, industrial, and municipal needs of its citizens.

(2) Hostility between two or more countries — or regions within a country - possibly leading to greater insecurity or conflict, caused by one party disrupting the water supply of another.

(3) The civil wars and terrorist acts in the region would affect the water security.
At this point I would like to add that, there is a general deficit in good governance, strong institutions, adequate financial investment, and political will. These factors are as much a cause of Middle East water imbalances as trends in population growth and economic development and these shortcomings are cause for more immediate concern. Specific water governance concerns differ across all nations in Middle East, but can be grouped into three broad categories:

1) Institutional and regulatory environments.

2) The tensions between central and periphery management.

3) Governance capacity.

The notion of water security in this context is linked to different actors' need to attain control and access to water resources in order to secure their vital interest on various scales and geographical levels, seen from a strategic, political, economical, cultural, environmental and social perspective. The fact that different actors have incompatible, competing, or conflicting strategic interests often create conflicts with varying intensity (Trondalen, 2008). As conflicts escalate, stakeholders will be exposed to conflict vulnerability, which in turn could be a threat to security or simply creating a sense of insecurity.

However, in the Middle East, access and control of precious water resources is vital from a security and strategic perspective. It is certain that the water problem is not confined to Egypt alone, but a problem plaguing the southern hemisphere and the Middle East areas in particular, as the water was a major cause for many of the tensions and skirmishes between some countries in the region closest to the mind and memory of the Turkish threat to cut off water from the Euphrates River in «1990 m »sparking fear and anxiety in both Syria and Iraq, and banished the media from time to time by threatening reality on the Nile in Egypt through Ethiopian government plans to establish dams on the Nile, which would reduce the flow of the Nile to Egypt, and if we turn toward the Jordan river basin, we find that the problem is exacerbated by the Israeli practices of robbery on the water and depriving Jordan, Syria and Palestine have the right to a fair in the water, and keep in mind that the Jordan River was the direct cause of the Arab-Israeli conflict, which led to the outbreak of war between the Arabs and Israel and the procrastination of Israel to give up all the occupied territories because they provide water to settlers and expansionist projects.

From this point the Israelis and the Arabs faces both vital issues on water and increases the population terrible will lead to increased competition for available water up to fierce water battles, and by the water hub of the episodes of the Arab-Israeli conflict. Since «1948» formed water early Zionists policies when they tried to establish the borders of the new state to be have the upper water resources - the Litani River, in particular,, and after more than 30 years was the attractiveness of these rivers located in Lebanese territory an important role in Israel's strategy, marched its army into Lebanon, as the water was an important factor in the silent war that took place for a period of ten years in Southeast Anatolia between Turkish troops and Kurdish ones elements PKK Kurdish-demands for autonomy. 


\section{International Journal of Science and Research (IJSR) \\ ISSN (Online): 2319-7064 \\ Index Copernicus Value (2013): 6.14 | Impact Factor (2015): 6.391}

Here I wish to refer to the population increase, which formed an ongoing population increases in major burden on water resources, and this is what made the politicians put the issue of water at the top of their agenda, and especially since the risks, prepared by the CIA «CIA» by evaluating papers estimated that there are at least ten sites in the world war can explode them because of diminishing shared water sources among its confirmed that most of these potential crises will occur in the Middle East, was among those expected possibilities it breaks probably between Syria and Turkey, in addition to other areas of the Middle East and this confirms that the $85 \%$ of the water flowing into the rivers that link to the Arab countries comes from upstream countries of nonArab, which makes the prospect of wars between the downstream states and the upstream countries based to a great extent, and perhaps this is why Egypt confirms more than once that it will not accept any threat to the security of the water, and previously, Israel has also threatened to attack Syria if it had carried out an individual for its part, building dams that will lead to reduced water flow to the sea of Galilee in northern Israel's water resources experts in Israel, Syria, Jordan, and recognizes the importance of these dams, but there's still always a party winner and another to pay the price, and drastic changes in the methods of water use in each of these three countries will not occur widen the circle of conflict between them sooner rather than later.

At the International Initiative for the Euphrates and Tigris river basins Irrespective of the political changes and even climate change scenarios, it seems obvious that a new, overarching international initiative must be taken:

First: The Euphrates and Tigris Basins Initiative (ETI) could be a partnership initiated and led by the riparian states of the two rivers through a Council of Ministers with the full support of the international community through international organizations such as Arab development banks and institutions, together with for example, the World Bank (in association with GEF and the United Nations).

Second: Following the example of the Nile Basin Initiative (NBI), which encompasses nine riparian African states, an ETI could start with a participatory process of dialogue among the riparian's that should result in agreement on a shared vision. For example, agreement could be reached on the principle of 'achieving sustainable socioeconomic development through the equitable utilization of, and shared benefit from, the common water resources of the Euphrates and Tigris basins. This vision could then be translated into a similar (to the NBI) Strategic Action Program with concrete activities and projects.

\section{Potential future conflicts in the Middle East}

There is no doubt that the stand on the issue and take note of them did not came in the current days, scientists and researchers alerted to the seriousness of the problem of water decreased and its role in future conflicts for a long time, and according to statistics, numbers, their studies and research has become with respect to many of the world of water in 2000, half the amount of water which was obtained in 1975, as studies have revealed that the Middle East in light of scarce water resources will become a position worse than many areas, in 1989, the population in the region reached 314 million people, an increase of $2.8 \%$ population became in 2000 nearly 423 million people, this figure will be doubled in a period of 25 years, these figures mean only that it will become a crisis with respect to a share of the region from the water with the knowledge that this crisis is not confined to the Middle East alone, but will be extended to include the whole world. in 2050, it is expected to be the world's population up to ten billion people are involved in the same amounts of water available today, DR. «Harwaldomatios» from the University of «Rio de Janeiro» says: the result will be that $40 \%$ of the world's population will suffer from water shortages in one way or another, and then armed conflicts be the way to get on the water.

\section{The Three Rivers}

Hotbeds of potential problems in the Middle East is not limited to the three major river systems in the region «Nile, the Tigris and Euphrates and the Jordan River» but conflicts also arise in areas where people and nations rely on stored quantities of water in aquifers between the rock layers and sand stones, for example, is the Hashemite Kingdom Jordan and the Kingdom of Saudi Arabia's, in recent times the use of Saudi Arabia of the stored water in the aquifers between rock layers sandstones of the groundwater reservoir is located on the border between Jordan and Saudi (AL DISI BAISIN), and if we take into account that it is imperative for Jordan to use this water due to population growth and the limited sources of the waters, so far Jordanian Govt started a big project from the southern part of the country to pump fresh water to the capital Amman, about (100 million cubic meter) per year in 2013.

The same is also reportedly on the Jordan River, which is considered one of the factors that can lead to conflict, has led to so already, war of six days in 1967 was an inevitable consequence of the Arab plan to divert the headwaters of the Jordan River, causing ignite a war between Israel and Syria, this in turn led directly to the creation of Israel under the guidance destructive blows to Syria, Egypt, and so the water has played a key role in the war between Israel and the Arabs in 1967, as well as in the bloody civil war in Jordan in 1970 and in the invasion of Lebanon in 1978 and 1982, and in military operations in eastern Turkey since 1983 onwards, and in the south conflict - the north, which led to fatigue Sudan for a long time, and if it is so- as it appears- it is properly that there will be new wars on water will spin on the land of the Middle East, which prompted Professor Elias Salamah, from the University of Jordan to say his famous words «The water will determine the fate of the Middle East.

The matter doesn't stop at this point, there is concern that the extension of water problems of the Middle East to include seemingly distant countries for a loop conflict in the region such as Ethiopia state geographically linked to Sudan and Egypt through the Blue Nile. With the establishment of new dams in Ethiopia with the help of Israel, it is likely to arise conflict between Egypt and Sudan, and add to that the dispute between Mauritania and Senegal on shared water resources, as described by expert this is one of the serious conflict areas that are likely to increase the unity of the military intervention, but that the world can avoid all these 


\section{International Journal of Science and Research (IJSR) \\ ISSN (Online): 2319-7064}

Index Copernicus Value (2013): 6.14 | Impact Factor (2015): 6.391

confrontations something one which cooperation, particularly and that there is no country in the Middle East have the ability to settle the problems until these political extremists like Tara fael Eitan » former Israeli Minister of Agriculture, knows earlier that the cooperation between Israel and Jordan is necessary to say the least.

Here we would like to note that the available phenomenon of water resources in the Arab world has very strategic importance of water security implications, which is that about half of these resources stems from the outside, so it is the next natural reasons, this makes these resources vulnerable to shortages and deterioration in quality as a result of strategy factors, or unfair uses, which shows underscoring the importance of working to develop international legislation that includes the rights of the Arab countries, and good implemented by all countries concerned.

The challenges facing the Arab water issues in addition to the high population growth, which will lead to a rise in its population of 350 million people in 2006 to 586 million inhabitants in 2026, requires a new ways to confront the water poverty and the widening phenomenon of desertification Arab food gap, and that means:

1) To adopt water strategy in the Arab world as a whole, and at the regional level (a set of common Arab countries in one river basin) and at the country level, rather than relying on the adoption of reactions to the positions of the neighboring countries.

2) The existence of a common Arab vision to address the Zionist plans aimed at the violation of Arab water rights that are forcing Israel to respect the peace treaty with Jordan in terms of water.

3) Raising the efficiency of water use through the development of systems and methods of the current irrigation.

4) Rationalization of water use, either directly or indirectly through pricing and the need to pursue policies that will expand in the high-value crops, used for less amounts of water, which is imposed by water scarcity in the Arab countries.

5) The need to use non-conventional water from sewage treatment and water desalination, through the support of scientific research and technology of water desalination, which is expected to evolve their use in Arab countries outside the Gulf region, and is a coordination between all the Arab countries in the development of scientific research in water use and negotiated in all regional and international forums, and to consider the Arab water security part of the Arab national security, is an essential input to reduce the aggravation of Arab water issue and the spread of desertification in the Arab world.

6) Establishment of conveying water from one region to another within a single country projects, and the transfer of water from one country to another (such as the peace pipeline project put forward by Turkey in 1987 on the Gulf, Syria and Jordan countries to provide them with water from a surplus of rivers of Seyhan and Ceyhan in southern Turkey)

7) Increase financial support for projects of Arab water by Arab finance institutions, and the creation of an independent Arab body of water holds the planning for Water and coordination between projects and conduct research on water and the promotion of Arab cooperation in this area and enact laws governing the use of shared water between one countries of the basin resources and the development of disciplines in aquatic Sciences in separate sections of the Arab League; in order to graduate specialized in this field of scientific competencies.

8) Identify sectors of desertification and evaluation, as well as adapt to the nature of climate variability and scientific planning for the use of land and reclaimed for agriculture.

9) Require Arab water security protection of water between agricultural authorities and consumer distribution, equitable and equal, and the development of the private collective action to address this problem, Green Belt project in which the share of the western Arab countries, would reduce the threat coming from the Sahara sand encroachment, The project to develop the Al-Hammad basin, which extends into its territory, Jordan, Saudi Arabia, Iraq and Syria borders, is an Arab joint venture, aims to develop the basin and reduce desertification .

10) Establishment of an industrial base for water technology and the establishment of an Arab center for training on modern technology in the field of water.

11) Paying attention to the education program of water engineering, particularly in the applied field.

12) Linkage between development plans and water policies.

13)Support the possibilities of scientific research centers and scrutiny priorities, such as the focus on the exploitation of solar energy in desalination. An advanced solar energy technology that can make desalination at low cost.

14)Achieving the highest degree of benefit from the global scientific research.

15)Extensive awareness of the masses in terms of water culture and achieve the cultural awakening that makes rational known use of water and wasteful denying campaigns.

16)Establishing a cabinet made up of ministers of the Arab Water and Water Resources to develop a common vision following the sophisticated tactics that serve the common international waters uses.

17)Finding an Arab fund for financial support of the Arab water security as are necessary to finance the various projects and research in the areas of water.

18)To meet the growing demand for water and the large gap between water resources and the demand for them, there should be the implementation of water resources development projects.

19) Expansion in the construction of surface reservoirs and streams where technically and economically feasible.

20) Exploring basins and hydrological mapping.

21) Develop sewage and industrial wastewater treatment to gain access to the closed session of the water in these areas.

22) Establishment of water desalination plants relies on solar energy available in abundance in the Arab world to minimize sweetener costs.

23) Develop the Arab and regional cooperation in the field of utilization of available water resources and development.

Although the countries of the Middle East-with the exception of Israel, still apparently betting on a diplomatic tool to address any dispute that may arise with regard to 


\section{International Journal of Science and Research (IJSR) \\ ISSN (Online): 2319-7064}

Index Copernicus Value (2013): 6.14 | Impact Factor (2015): 6.391

water released, except that if the search for a political settlement, the key problem is that there are real difficulties on reaching an equitable division dwindling water resources, especially in the Levant region, due to the increasing Israel's water resources need eye- due to the constant desire to bring more immigrants. Thus, the military tool may present itself in the future stages of a conflict of wills between Arabs and Israelis' a long conflict in the past for a period of more than half a century on the water. WE can even foresee conflict scenarios for water in the region by addressing the analysis of the degree of balance of the resources: requirements and plans and projects put forward in the light of the objective reasons that could lead to an increase in the degree of conflict over water in the Middle East or reduce the degree of unity.

\section{First: The dialectic of conflict over water in the Middle East.}

The dialectical conflict on water is due to the nature of the geo-strategic situation of the Arab World / Middle East. That is the issue of water in this area -as explained earlier- which is of the most controversial and, disagreement and wrestle issues. Alongside it, social, legal and technical economic issue, it is a matter of security and strategy at the same time, about the life of the region and its peoples, and intertwined with other problems spawned them in the past - it may increase in the future-disputes and armed conflicts., such as borders and the problems of occupation and expansion and minorities. In addition, Israel and Turkey should take a look forward to the regional role through the issue of water.

It is expected that the issue of water remains in the Middle East remains crucial point and it is related to focusing on relations between countries in the region. Those relationships may witness various forms of friction, ranging cooperation and the end of the armed conflict, through tension and threatening of using violence.

We can relate the reasons and motives that lie behind the conflict on water, and the prospects for its transformation into an armed conflict, to three main reasons:

a) The occurrence of the most important sources of water outside the Arab land.

b) Decreasing the relative share of the water.

c) Direct aggression by word or act - on Arab rights of the water.

And despite the fact that all of these reasons for are not connected at least in theory, but they are connected with each other to some extent by large scientific point of view. The downstream countries are frequently in a weaker position than the upstream countries because of recent control in the initial distribution of the water cycle. Thus, the occurrence of the most important sources of river springs outside Arab borders could tempt some greedy times in to influence Arab Lots of water going in those various routes ranging from denying the Arab rights in some of the crises to the Arab in shared water [the case of the Euphrates River] passing of trying to shirk their obligations international and contracts shared waters [case of the Tigris river ] and ended by being free of commitments of assaulted or coerced by military force water in the Arab-Israeli conflict.
Accordingly, the integrated analysis of the reasons mentioned requires the need to take the controversial nature of the overlapping of these reasons in mind.

\section{First, the occurrence of the most important sources of water outside the Arab land:}

This factor is linked to the nature of the environmental and geographical situation of the region, with the headwaters of the river Nile and the Euphrates and the Tigris outside the Arab land, and this is what makes more than 85 percent of Arab water resources under the control of the to a non-Arab parties, you can use water for political and economic tool against Arab interests, whether in the circumstances of the differences political or in the light of the economic and life needs opposes, in addition, the Arab development plans become under wills conflict in the Middle East-are prone to a variety of threats and associated procedures and capabilities beyond the Arab will.

\section{Second, decreasing the relative share for the Arab States of} the water:

The scientific studies indicate that the per capita availability of water in the Arab region will decrease with severe and serious shortage. This shortfall represents the result of a combination of natural, economic and political variables varied. And it includes natural variables on desertification, pollution and Stalinization.

The economic variables are related to the likelihood of increased need for water use at the geographical neighboring countries due to population growth and the growth of water consumption, dams, irrigate the land and convert new streams of some tributaries.

This corresponds to the need for the Arab States of the water for the same reasons, and in particular that the size of water shortage in the Arab world/reached in 1991 to $44 \%$. Although the amount of water used in agriculture represents more than $60 \%$ of the grain. The political changes concentrated mainly in the aspiration of the neighboring countries to play regional and influential role in the Middle East, which is paid to attempt to control the sources of food, specially the water in the region.

Third: direct aggression on the Arab rights in the water:

As we have already explained the history of water relations in the region on a proven track record, both direct and indirect attacks by Israel on the Arab water resources. In addition to putting the Israeli occupation authorities of the water resources of the West Bank and Gaza Strip since 1967 under its direct control, Israel has always sought to penetrate the head waters of Arab rivers and springs by working to disturb the relations between the one-basin countries, the infrastructure to we have referred to in relation to the Nile River. A number of analysts also believe that the reasons for Israel's adherence to the Syrian Golan Heights were primarily due to the water reasons.

On the other hand, we find that the World Zionist since the beginning of the century put the southern Lebanese waters of the Litani in mind, where Israel found the perfect opportunity with its invasion of Lebanon in 1978 and swept it in 1982 where press reports and the semi-official reports 


\section{International Journal of Science and Research (IJSR) \\ ISSN (Online): 2319-7064}

Index Copernicus Value (2013): 6.14 | Impact Factor (2015): 6.391

stated the stealing of Israel to much of the water of that river - Presumably for this reason that Israel will continueits refusal to withdraw from south Lebanon unless it gets the spoils of war from water.

In light of the foregoing intersect three dimensions mentioned together, which make up the total cases of conflict of interest, which may be reflected on all regional relations in the future.

\section{Second: The probability of the development of conflict on water.}

Water wars are coming! It seems obvious rivalries over water have been the source of disputes since humans settled down to cultivate food. Even our language reflects these ancient roots: "rivalry" comes from the Latin rivals, or one using the same river as another. Countries or provinces bordering the same river (known as "riparian's") like, Turkey, Syria and Iraq, and even for the Nile case Egypt, Sudan and Ethiopia are often rivals for the water they share. As the number of international river basins (and impact of water scarcity) has grown so do the warnings that these countries will take up arms to ensure their access to water. In 1995, for example, World Bank Vice President Ismail Serageldin claimed that "the wars of the next century will be about water."

Conflicts can arise from the use of common water resources. In order to further our understanding of such conflicts it would be appropriate to distinguish between conflict arising through use, and conflict arising through pollution. A utilization conflict, for example, could be the construction of a power-station on the upper-course of a river.

Although there are some opinions of the view that the next war in the Middle East is the water war, we see that there is uncertainty regarding the nature of the goals that can be used for which military force in the case of water conflict in the Middle East, as well as about the potential of this military force employment forms. Accordingly, we will address each individual case as follows:

\section{1- The case of the Nile:}

Despite the presence of some of the advertised differences that arise between the Nile Basin countries between now and then, but these differences do not express fact of the existence of conflicting positions between the different parties in connection with the issue of water, where disputes over water usually associated with political differences. The best evidence of that happening between Egypt and Sudan from time to time and what happened between Egypt and Ethiopia in the late seventies.

The river systems of the Euphrates, Nile and Ganges are characterized by a flow that, although plenteous in the upper basin, is drastically reduced in the lower basin because of the extensive use of the resource among the upper riparian's. As a result of this arrangement, the needs of the lower-lying states are not being satisfactorily met. This is especially prevalent in the cases of dam construction, reservoirs or extensive irrigation works which reduce water availability. Examples would include the Ethiopian highlands dams in Ethiopia. In these cases we find a conflict over distribution where the water flow to the lower-lying regions is seriously hampered.

When Ethiopia's Marxist-oriented military regime came to power, which is linked to political and military close ties with the former Soviet Union, at a time when the Egyptian political leadership linked to a tied relations with the United States, , the political differences between the two sides broke quickly and was reflected on the water issue. It has been demonstrated clearly, when President Sadat announced the possibility that Egypt will supply Israel with Nile water, and despite the fact that the Egyptian announcement dr. Mustafa Khalil, the former Prime Minister -who stated it was just a bargaining chip to tempt Israel to soften its stance in the peace talks were taking place at the time did this announcement as an idea to enter into force as never not been discussed and died forever according to Mustafa Khalil, but Ethiopia quickly protested Egypt and has been accused it of misusing its share of the Nile water. In this context, Ethiopia in May 1980 filed a note of protest to the Organization of African Unity, also number of Ethiopians writers, including and Ndimnah Tilahun, a professor at the University of Addis Ababa remembered of what they claim the existence of an imperial ambitions of Egypt in the Blue Nile and Lake of Tana.

The two terms in the eighties and nineties, the Egyptian politics has tended toward re-opening to the countries of the African continent, including Ethiopia. And it focused on improving political and economic relations with it, and to waive the successive setbacks that took place in relations during the seventies. This Egyptian desire to have received in response to Ethiopia's similar in the era of the new system was crowned the Cairo Agreement in the $1 \backslash 7 \backslash 1993$, an agreement which was signed by Presidents Hosni Mubarak and Meles Zenawi in order to create the framework of general cooperation between both countries for the development of the Nile water resources, and to promote economic and political interests, and in order to achieve optimal use of resources and the potential of the two countries.

Thus, the dispute Egyptian Ethiopian around the water was, in fact, as a part of a whole network of interactions between the two sides, where the dispute arises in times of crisis in relations, and the rest in periods of mutual cooperation, and the most important attributes that dispute, the two Egyptian and Ethiopian sides focus on the use of diplomatic tools, and seeking in this context to find a suitable cooperation and coordination in the use of the Nile water formula.

Regarding the differences, if any, with other Upper Nile states, they were not raised publicly has never having mutually hostile statements on the Nile water with those countries.

Accordingly, the diplomatic tool is almost the only tool to be at the present time to resolve any dispute that may arise between the Nile Basin countries, while not excluding other tools rising gradually in the case of changed circumstances occurring in the local, regional and international environment is a fundamental change. 


\section{International Journal of Science and Research (IJSR) \\ ISSN (Online): 2319-7064 \\ Index Copernicus Value (2013): 6.14 | Impact Factor (2015): 6.391}

\section{2- The case of the Tigris and Euphrates:}

There is no doubt that the dispute on the waters of the Tigris and Euphrates rivers is generally associated with aspirations of Turkey to have a influential regional role in the Middle East. In this context, Turkey gave itself the right to act in the waters of the Euphrates and the Tigris in line with the political and economic interests and ignoring the rights of the beneficiaries of them Arab countries [Syria and Iraq ], not least because of the insist of Turkey at the moment to press ahead with its large-scale South project eastern Anatolia [GAP]], which aims to provide the border areas of Turkey's energy and sources of irrigation to make a compilation of grains points, fruits and vegetables [Middle East breadbasket], a project that felt by many Arab experts that - in the case of its implementation -it will enable Turkey to play an effective and influential role in the Region. This comes along with the launch of turkey the project of [cross-border] on the Tigris and Euphrates, instead of the [international] recipe but some Turkish statements go to be reckoned when claiming the two rivers are Turkish and they derive entirely from Turkey.

Moreover, The Euphrates and Tigris originate in Turkey. However, for geographical reasons (its population and industrial centre is in the north rather-than the south), Turkey has to date only utilized a small part of this water resource. In contrast, the water needs of Iraq are almost totally dependent on the flow from the Euphrates and Tigris, while Syria depends heavily on the Euphrates. Both states need the Euphrates for political human water-consumption, for irrigation projects and for the generation of electricity. As a consequence, all three states have erected a number of dams. Understandably, considerable political tension has arisen among these states. This was illustrated in the 1970s when the construction of the Assad Dam nearly ended in military conflict between Syria and Iraq. A standing source of conflict between the three is also the Kurdish problem.

However, it is unlikely that the dispute of Turkish-Arab to be developed into the conflict or an armed conflict in the near future, not only because the balance of military power does not allow such a move by the Arab side, but also because the disagreement space about this issue has not yet reached a serious amount, but is how to find a formula to keep the vital Arab interests in the water in the face of Turkey's aspirations to play a meaningful political and economic role.

But yet nobody knows of what will happen when Turkey begins to follow the rest of the construction of dams on the Euphrates River, and it became clear negative impact on irrigation projects and power generation projects in both Syria and Iraq. On the other hand, unlike the Turkish announcement of the peace pipeline deep sense of skepticism toward the Turkish intentions of both Iraq and Syria. And because of this uncertainty in the Turkish intentions that Turkey would deprive the two states were benefiting from water naturally Syria and Iraq] in order to other parties in who can benefit them all in favor of Turkey, which will use surplus water, which will be available to have and the amount of 6 billion cubic meters of water a year to confirm its regional role and get the material return rewardingly may amount to substitute oil with water. In the case of the success of Turkey in the play this role perfectly, it will support the role of NATO in the South Atlanta as guard of its south gate.

The deadlock over the introduction of an agreement is monthly increasing the waiting costs for Syria and Iraq while allowing Turkey to consolidate its position. Although Turkey, as the upper-lying state, is the dominant power, it too could gain from the signing of an agreement. An agreement could release the consent of the riparian states to the lifting of the blockade on international credit. Currently construction is financed by French concerns. Furthermore, Turkey could also proceed with the export of agricultural products, electricity and water to its neighboring states, an issue which has till now been linked to and therefore hindered by the water question. Finally, a closer working relationship among the three states could result in a more readily achieved solution to the Kurdish problem. However, to date there have only been a few bilateral agreements between the three states. With the 1987 agreement Turkey granted Syria $500 \mathrm{~m} 3 / \mathrm{sec}$ of the available $950 \mathrm{~m} 3 / \mathrm{sec}$ flow of the Euphrates. In 1990 Syria divided this share with Iraq $290 \mathrm{~m} 3 / \mathrm{sec}$ to $210 \mathrm{~m} 3 / \mathrm{sec}$ respectively. However, Syria and Iraq are calling for an increase to $700 \mathrm{~m} 3 / \mathrm{sec}$, an increase which would reduce Turkey's share from $450 \mathrm{~m} 3 / \mathrm{sec}$ to 250 $\mathrm{m} 3 / \mathrm{sec}$. The water conflict has also had a decisive influence on the power structure of the region. The formation of a common front against Turkey is bridging the barriers between Syria and Iraq and their previously incompatible leaders, Hafiz al Assad and Saddam Hussein. In turn, Turkey has strengthened its political, military and economic ties with Israel. A new power parallelogram is emerging which will have far reaching effects for the region as a whole.

\section{3- The State of the Jordan River basin and the waters in the circle of the Arab-Israeli conflict:}

There is a long history of water-related disputes, from conflict over access to adequate water supplies to military attacks on water system during wars. Water and water supplies systems have been the roots and instruments of war. Access to shared or disputed over riverbeds has been cut off for political and military reasons.

The case of the Jordan River basin represents one of the most serious cases because of the growing ambitions of Israel in the Arab water resources both in the groundwater in the West Bank and Gaza or in the waters of the Litani, river Jordan and Yarmouk, while Jordan urgently needs for more water.

What evidenced by the tension that has happened this year [1997] between Jordan and Israel because of the water, which on its impact was canceled a meeting scheduled between Prince Hassan, Crown Prince of Jordan at the time, and Benjamin Netanyahu, Israel's prime minister in Bakura area, where Israel has refused to implement the obligations contained in Annex V of the agreements signed between the two countries on 26 April 1994 on the water peace agreement, after the Jordanian government had made proposals to provide the country with an additional 50 million cubic meters of water in accordance with the peace treaty by one of its clauses stipulated that the parties search 


\section{International Journal of Science and Research (IJSR) \\ ISSN (Online): 2319-7064}

Index Copernicus Value (2013): 6.14 | Impact Factor (2015): 6.391

for the source of this quantity within a year of exchange of the Treaty documents, In addition to the expansion of the storage capacity for flood waters of the Sea of Galilee, which is currently up roof [1997] to 20 million cubic meters.

The result is that Jordan rejected an Israeli proposal to establish a joint venture for water desalination contributes to Jordan in its financing in order to secure the disputed waters. Amman has justified its position of the economic useless of the project. Accordingly, and in light of the increasing decline in the water in both Jordan and Israel, the water element in the -Arab conflict and Israel, water is considered one of the elements of causing conflict, despite multiple parties on water negotiations.

Indeed, there are many indications to believe that Israel will insist on getting the lion's share of water from neighboring Arab countries, but even so it requires using of the military force employed by Israel always when things go sour. It is through our reading of the three elements of the following:

1) The relationship between water and strategies of Zionism since 1882, when the first colony founded (Petah Tikva] in Palestine, until the creation of Israel in 1948.

2) The relationship between the water and the Israeli military strategies and possibilities successive Arab territories through all the wars and battles waged by Israel since its establishment until today.

3) The relationship between water, strategies and prospects, where Israel aspires to achieve through the means available to it, either by using the correct balance of power in its favor in the framework of the [peace negotiations] or the threat of use of armed force or actually use on a limited scale [as a process of southern Lebanon in 1993] or Wide.

Our reading of these three elements, and the linking of actually of water in Israel and the need for increased water in the light of the influx of Jewish immigration, especially the large influx of Jewish immigrants from the countries that were part of the Soviet Union dissolved, and states that were part of the Warsaw Pact fading, a flow exceeded every conceivable and prospect.

All of this leads us to draw a number of the most important results, that in spite of Israel has been complaining traditionally from a shortage of water resources, but the basic needs have increased at high rates in recent years, and that due to the increasing water consumption resulting from the growing number of Jewish immigrants to Israel, as well as diminished the amount of water coming from sources that already exist, where the increased water complexes salinity as a result of the extraction of fresh water and increased salinity in the course of the Jordan River south of Tiberias, also it decreased groundwater as a result of the lack of rain water in addition to the drought many ground water wells in the West Bank and the Golan Heights.

For all these reasons, there is the possibility that Israel will carry out new acts of aggression to seize more Arab water especially in light of Prime Minister Benjamin Netanyahu's policy volatile. The options in this regard in three:
First: The continued control of the groundwater in the West Bank and Gaza Strip.

Second: The seizure of Yarmouk River waters.

Third: The expansion of the Litani River water theft.

Upon implementation of these options, Israel will not need to use military force. Only in the case of camion the expansion of the seizure of Yarmouk River waters. It is possible that Israel offers already on the implementation of this process in the case of the availability of adequate international and regional environment. In any case, it does not seem that Israel could face an effective Arab resistance in light of the balance of power is unequal, both on conventional or unconventional weapons between the two sides in favor of Israel, as well as the fragility of the Arab political coordination and a lack of military alliance.

All these reasons may help Israel to fabricate pretexts for armed aggression on Arab land adjacent to get a hand on the Arab water resources or the confiscation of Arab water rights, which is the behavior that apply the preventive policy 'to look like its offensive deter the Arab side for the defense of their land or their rights of water, to achieve its purpose without a fight, but with threatening of

First: Use of force, an offensive force in the composition of a deterrent in its ability, and if the threat does not work, use of the weapon which is the alternative.

Due to our experience of Israeli pattern of thinking, the success of the allied air forces in the Second Gulf War which enable them to achieve traditional deterrence, it may be tempting for Israeli forces to follow a similar approach, especially as it is able to get a special technology for these operations from USA, as it enjoyed superior air forces can increase their capacity easily. And Israel can persuade the concerned parties to - such as the US Of the operations desired by Israel will be the aim of securing the needs of Israel's water for a long time to come and it will be useful and almost without problems, and more so the lack of balance, which was caused by the presence of the Soviet superpower in the international arena, in addition to this, the parties which might be directed against these scientific do not always get the desired extent of coordination between them [to Lebanon, Jordan, Syria] and the Arab position generally rickety and passes periods of weakness separation. In contrast, Israel has a potential in arms over the conventional and WMD, which could make it safe from any reaction if it occurs, it is likely that Israel has come to be launching such an operation is appropriate, as this will reduce the new immigrants problems and to live with new community, which joined them and renew military expertise of Israeli society based on the foundations of military superiority.

In short, a review of axes of conflict over water in the Middle East shows that all of these axes are multiple risks that the most serious of which stems from Israel, which has for a long time on the waters of the neighboring Arab states should set its sights threats. During the coming period, it is expected to increase Israeli studied and designed plans to grab more Arab waters. This seems to be a possibility, not only in light of the increasing - Israeli water needs to 


\section{International Journal of Science and Research (IJSR) \\ ISSN (Online): 2319-7064}

Index Copernicus Value (2013): 6.14 | Impact Factor (2015): 6.391

facilitate the absorption of Jews in Arab lands, which is still possible, but also in light of the case of the disintegration of the political Arab position and the military and the fragility of coordination between the various Arab parties, which opens the door to the neighboring countries of the geographical Arab nation to implement their plans, expansion of border and how they see the water and with little compared to an Arab.

Third, The issue of the armed struggle for water

If breaks out wars on water without another reason - in the Middle East, it is expected that this war will be in different circumstances of each that accompanied the wars that took place in the period between the end of World War II until today because the strategic features of the wars of possible future water will not those that carried previous wars, and would put conditions and international variables and the mechanism of international legitimacy restrictions on shared water wars parties to be lightning in the short-term goals is dilated temporal spatial framework.

It could be argued that the issue of water, which increases the political game, leaves them in the Middle East, ranging in features on the basis of the current water situation of current and future needs.

1) Danger zone: which has intense thirst and interacts with the sources of the dispute and the intervention in which Jordan, Syria, Lebanon and Palestine with Israel where interact axes religious differences and the cultural, political and constituent Arab-Israeli conflict that the economic is still in place despite the peace negotiations a circle currently?

2) The potential danger zone: an area that has a selfsufficiency of the water now, but could face an imbalance in the water balance in the future, and the intervention in which the countries of the Arabian Peninsula and the Gulf and the Tigris and Euphrates basin:

3) Tension region: It is not yet up to the level of potential danger but from time to time some of the tensions, including Egypt, Sudan and Ethiopia.

The standard, which was founded by the zoning was not only the risks that threatened or threatening water security in the Middle East, the size, the risk varies between probability likely and a low probability, from one region to another, if the increased risks and prospects becomes bigger- if we're not semi sure - Jordan area and its tributaries and southern Lebanon, any area that Israel looted waters, the risks are less severe, and the possibilities less merit in the northern region, i.e. the region where Turkey is seeking to acquire discretion waters of the Tigris and Euphrates to achieve its interests first and foremost, without taking into account the rights of Syria and Iraq. In the Nile basin area, despite the rumors about the growing fingers of Israel, when the Upper Nile, particularly in Ethiopia, the probability is likely to prevail understanding and coordination between the Nile Basin countries and be understanding upstream countries, with Egypt and Sudan, the nearest of difference with them.

We could imagine a mechanism for the phenomenon of war, which could take place in the region for water, and then we may outlook that armed conflict could crosses five stages, these features:

The stage of crystallizing the tension: this stage consists in water problem, and takes the form of tension; it has alternated diplomatic contacts, joint committees, and means of private mediation compromises. The matter reached the point agreement wrapped up the problem, although not as well as the reasons of conflict will remain dormant.

If we want to pass on this, saying to fruition, we can say that the reasons are latent conflict in the waters of the Euphrates problem [between Turkey on the one hand, and Syria and Iraq on the other hand, and in the waters of the Jordan problem and Yarmouk [between Israel on the one hand and Lebanon on the other hand].. In the basin of the Nile River, the problem is at a standstill for the time being, since factoring is excited.

The stage of threshold Conflict: The maturity of the water problem in stage transmitted to the frame work of the strategic military thinking, propaganda policies in preparation of armed conflict, and the threat to it, through media campaigns and the campaigns of anti usually focus first on preparing the home front as a prelude to accept the decision of war.

The outbreak of war: At this stage, the stage explodes position. The experience of previous wars in the region has shown that war is frequently cursory spatially limited in time, and in our perception that the wars of water in the framework of the current Arab reality, may be bilateral or trilateral, do not exceed the participation of the relevant water problem countries. I.e., we collectively brought down the Arab military action as it cannot be achieved only if the Arab countries in the framework of the Arab university agreed that water/security is part of the Arab national security, and that the damage done by any party other than the Arab detriment of the Arab national security and endangering peace in the region at risk, and Arab rights in water resources that flow or pours or pass in the Arab world, as with any Arab land. What is left on the ground and keep them shared its defense, it left the water alike.

The stage of the war: at this stage all forms of armed conflict are stopped, either the triumph of one end of the war on the other, and either stop fighting on the basis of 'no victor and surrender and go away without at the same time the causes of conflict and manifestations.

Settlement and satisfaction stage: at which point, then eased the crisis, through negotiation or - to solve the cases, without regard to the factors that drive each party to back.

It is noted that these stages are not governed compulsory, the war emanating from the first phase [crystallized the conflict] settlement has been progress achieved [fifth stage [during the third stage [the outbreak of war] or from the first phase 'crystallized the conflict'. The war has repeated in reciprocal forms of escalation and relaxes. And this may be repeated shapes and overlap each other in some stages, even to end the dispute settlement or victory or stalemate or even cooperation. 


\section{International Journal of Science and Research (IJSR) \\ ISSN (Online): 2319-7064}

Index Copernicus Value (2013): 6.14 | Impact Factor (2015): 6.391

\section{Conclusion}

From the previous elements, we could make sure of the seriousness of water issues at the global and the Arab level in particular and that there are old fundamental political targets and in the major countries strategies for the control of water resources outside their territories, in addition to what it water issues involve of economic and social dimensions. Therefore, the Arab world must realize once again the dangerous of the situation and to rearrange its papers to preserve what remains of its water resources and adopt a unified Arab strategy to realize Arab water security dimension of what causes the water poverty.

However, after analyzing water as a political and conflict risk factor in the Middle East, scholars typically emphasize the inter-state dimensions of this question and concentrate on the Trans boundary water resources in the area. This is, of course, a relevant and important point of view, given that many of the region's central waterways are shared by several riparian countries. Yet, as argued in some recent studies, the internal, often local, conflicts over water and the consequent insecurities can pose a greater challenge for the Middle East than inter-state water conflicts.

At this point I would say that, The Middle East region has been fortunate in that it entered its period of progressively more serious water insecurity in an era when water in the global system was readily available, subsidized, and affordable in international trade via food staples. In the coming decades, the Middle East will be self-sufficient in neither food nor water, and as a result will suffer some level of insecurity. Virtual water imports will continue to provide the solution. Until 2000, they have been economically invisible and politically silent. One or more decades may pass before the peoples and governments of the region can publicly state their dependence on the global system. It is difficult to predict when the veil of ignorance will be lifted so that all water users in the region will become aware of the relative contributions of regional and global water to their water security.

The coordination and cooperation between all Arab states and adopt a common water policy will be a guarantor in the finding easier and less expensive solutions, and this was confirmed by a lot of specialized studies published in the Arab world in recent years, adding that many of the strategic centers of regional, Arab and conferences had recommended the need to adopt this trend as the only way irreplaceable in overcoming this problem, which began to worsen significantly, that dangerous dangers imminent if they are remedied quickly.

This means that the Arab countries cannot rely on renewable freshwater resources in their territories, as they are enough to meet only $61 \%$ of their needs, and there is no doubt that the natural sources which are located outside the Arab States region are not guaranteed nor safe because other countries control them and therefore these sources will be subject to the constant threat which require the intensification of efforts to draw the correct methods and adopt the correct strategy by all Arabs of these countries direction in order to achieve the minimum guarantee of the security of the water
It remains also significant to point out that the water situation in the Arab countries are worse than many developing countries unless they are able to exploit effective water resources exploitation, we been using the traditional methods of irrigation that leads to a huge waste of water constantly and the misuse of some countries in the exploitation of resources of underground water that has led to salt water intrusion aquifers increasingly, and this is noted notes that in the coastal areas of North Africa as well as in the Arabian Gulf region, and this is the result of the absence of agricultural awareness and not using scientific plans in irrigation, agriculture and delayed access to new methods reached by the human mind in the ways of modern Perfusion known to much of the world from the first decades of this century of course,, which is still continuing development toward disclose all what they believe to control of water exploitation and preservation of the consumer thought ways.

The crisis is completely overlapping; it is in fact a global crisis specially on the Arab region wealth sources and the exploitation of its resources and its details in favor of the movement of social progress and the development of civilization, and therefore we can say ,for sure in this case, that the solutions reached by the developed countries and adopted in their countries did not fit with the Arab countries as studies state for many reasons, so it looks like now is a crisis and third world poor countries in water resources

Given the international agreements, whether public or private, which was held to regulate the use of waters of international rivers in the non-navigation affairs, we can draw a broad base, these international conventions and treaties aim to ensure the rights of the riparian States in the international waters of the river and through the preventing the riparian states do projects to exploit water without the approval of the States concerned or by explicit statement of the duty to respect the rights of the riparian states ,distribution of water between them to prevent the takeover of some of the rights of others or damaging the other party.

Finally. To illustrate, crises in four regions in the world we would put it this way, all with a different history of water issues will be summarized. Three of them involve neighboring countries within a larger unstable area, a coincidence that could further aggravate their individual conditions. The first, South Asia, describes a basin without a permanent water-sharing agreement. The second, the Nile River basin, is saddled with a disputed colonial allocation of resources awarded to one of the ten riparians. The third, the Middle East, has two basins in crisis, one with a dominating riparian, another where one riparian gained full control of the resources through prolonged military actions. The fourth illustrates the new phenomenon: wealthy countries short of water securing long-term arrangements for agricultural production to serve their own needs. Following the summary of the regional water disputes, a discussion is offered on the seeming ineffectiveness of the international community's present organizational arrangements and agency charters and a suggestion for more productive deliberations to meet the urgent need for action now. 


\section{International Journal of Science and Research (IJSR) \\ ISSN (Online): 2319-7064}

Index Copernicus Value (2013): 6.14 | Impact Factor (2015): 6.391

\section{References}

[1] Vella, J., 2012: The Future of Food and Water Security in New Egypt. Future Direction International.http://www.

futuredirections.org.au/publications/food-and-watercrises/813-the-future-of-food-and-water-security-innewegypt.html (accessed August 23, 2013).

[2] Brochmann, Marit \& Gleditsch, Nils Petter, (2012): Shared rivers and conflict - A reconsideration, Political Geography,31.

[3] Grey, David; Sadoff, Claudia. (2007), Sink or Swim? Water security for growth and development, Water Policy, 9 number 6, IWA Publishing.

[4] Brochmann, Marit \& Hensel, Paul R. (2011): The Effectiveness of Negotiations over International River Claims, International Studies Quarterly 55.

[5] Butts, Kent H. (1997): The strategic importance of water, Parameters 27 (1).

[6] Buzan, Barry \& Hansen, Lene, (2009): The evolution of international security studies. Cambridge: Cambridge University Press.

[7] Clark, Ian (2011): Hegemony in international society. Oxford: Oxford University Press.

[8] Conca, Ken, Wu, Fengshi \& Mei, Ciqi, (2006): Global Regime Formation or Complex Institution Building? The Principled Content of International River Agreements, International Studies Quarterly 50.

[9] Devarajan, Shanta, (2014): Corrosive Subsidies, Middle East and North Africa Economic Monitor, Washington: World Bank.

[10] Dinar, Shlomi, (2009), Scarcity and Cooperation Along International Rivers, Global Environmental Politics 9.

[11] Dinar, Shlomi, Dinar, Ariel \& Kurukulasuriya, Pradeep (2011), Scarcity and Cooperation along International Rivers: An Empirical Assessment of Bilateral Treaties, International Studies Quarterly 55.

[12] Dohrmann, Mark \& Hatem, Robert (2014), The Impact of Hydro-Politics on the Relations of Turkey, Iraq, and Syria, The Middle East Journal 68 (4).

[13] Falkenmark. Malin, (1989), the massive water scarcity threatening Africa-why isn't it being addressed, Ambio 18 (2).

[14] FAO (2003): Review of World Water Resources by Country, Water Reports 23, Food and Agriculture Organization of the United Nations.

[15] FAO (2008): Irrigation in the Middle East region in figures, AQUASTAT Survey, FAO Water Reports 34, Food and Agriculture Organization of the United Nations.

[16] FAO (2015): AQUASTAT database, FAO's Information System on Water and Agriculture, Food and Agriculture Organization of the United Nations.

[17] Fawcett, Louise, (2005), International relations of the Middle East. Oxford: Oxford University Press.

[18] Gilpin, Robert, (1987), the political economy of international relations. Princeton: Princeton University Press. Politikon: IAPSS Political Science Journal Vol. 27198.

[19] Bethany \& Owen, Taylor, (2006, Conflicts over shared rivers: resource scarcity or fuzzy boundaries?, Political Geography 25.
[20] Gleick, Peter H,(1993), Water and Conflict. Fresh Water Resources and International Conflict, International Security 18 (1).

[21] Granit, Jacob \& Löfgren, Rebecca, (2010), Water and energy linkages in the Middle East, Paper 16, Stockholm: SIWI.

[22] Granit, Jacob \& Joyce, John, (2012), Options for cooperative action in the Euphrates and Tigris Region, Paper 20, Stockholm: SIWI.

[23] Greenwood, Scott (2014): Water Insecurity, Climate Change and Governance in the Arab World, The Middle East Policy 21 (2).

[24] Hensel, Paul R., McLaughlin Mitchell, Sara \& Sowers, Thomas E. (2006), Conflict management of riparian disputes, Political Geography 25.

[25] Homer-Dixon, Thomas F. (1991), On the Threshold: Environmental Changes as Causes of Acute Conflict, International Security, 16 (2).

[26]El-Agha, D.E., Molden, D.J. and Ghanem, A.M., (2011), Performance Assessment of Irrigation Water Management in Old Lands of the Nile Delta of Egypt, Irrigation and Drainage Systems.

[27] El-Nahry, A. H., Doluschitz, R.,(2010), Climate Change and its Impacts on the Coastal Zone of the Delta, Egypt.

[28] El-Sadek, A., (2010), Virtual Water Trade as a Solution for Water Scarcity in Egypt, Water Resource Management.

[29] El-Ramady, H.R., El-Masrafawy, S.M., and Lowell N. L., (2013), Sustainable Agriculture and Climate Changes in Egypt, Sustainable Agriculture Reviews, 12, 41-95. http://link.springer.com/chapter/10.1007/978-94007-5961-9_2 (accessed August 10, 2013).

[30] Hamouda, M.A., Nour El-Din, M.M. and Moursy, F.I., (2009), Vulnerability Assessment of Water Resources Systems in the Eastern Nile Basin, Water Resource Management, 23, 2697-2725.

[31] Houri, Ahmad and Jeblawi W. El, Saadieh, (2007), Water quality assessment of Lebanese coastal rivers during dry season and pollution load into the Mediterranean Sea. Journal of Water and Health, 5, 04, 615-623.

[32] Hreiche, A., (2009), Irrigation needs and management. In MED EUWI National policy dialogue on integrated water resources management planning in the republic of Lebanon. Greece: EU Water Initiative.

[33] Ministry of Water Resources and Irrigation, 2005: Water for the Future: National Water Resources Plan 2017. Arab Republic of Egypt, Cairo.

[34] World Bank, 2009. Lebanon Social Impact AnalysisElectricity and Water Sectors.

[35] World Bank, 2010. Republic of Lebanon Water Sector: Public Expenditure Review.

[36] World Bank, 2012. Lebanon Country Water Sector Assistance Strategy.

[37] World Bank, 2013. Country data. Accessed online in August 2013

at: http://data.worldbank.org/country/lebanon.

[38] Al-Ahram Weekly Online.

[39] Al-Ahram Newspaper. Egypt.

[40] Al-Rai news paper. Jordan.

[41] Al-Bayan news paper. UAE.

[42] Al-Qabas news paper. Kuwait. 